\title{
Criança: qual o mundo para ela? 69
}

\section{Ana Cristina de Araújo Cintra 70}

Sou convidada a esta mesa acredito que principalmente pela experiência de 23 anos no Acaia, que começa como um lugar de estar e, embora tenha se alargado em tamanho e ofertas, permanece essencialmente com esta possibilidade aberta.

(daqui pra frente minha voz estará em off e ilustrará o que falarei em um pequeno vídeo)

Localizo a região do Acaia, zona oeste de São Paulo, próxima ao CEAGESP e que vem se transformando de uma área de galpões industriais para conjuntos residenciais e empresariais de classe média alta ao longo deste tempo.

Em amarelo está a sede do Acaia, em vermelho o conjunto Cingapura madeirite e as duas favelas, a da Linha e a do Nove. Nossos frequentadores vêm majoritariamente destes três locais. O nome Acaia tem origem tupi-guarani e quer dizer útero, um espaço de acolhimento, crescimento e encaminhamento para o mundo.

Na foto aérea, feita por drone, podemos ver a favela da Linha tomada por construções em volta. Ouvimos de uma criança, "tá faltando ar na favela".

Compartilho com vocês um gráfico que busca evidenciar o que vou apresentar: qual o mundo para uma criança? Uma criança precisa de uma aldeia inteira para ser educada, dizia um provérbio africano, uma criança, eu diria, precisa de um entorno de sustentação para seu vir a ser. Neste gráfico temos nosso aluno/frequentador do Acaia no centro e no entorno, as diversas ações que organizam e suportam seu desenvolvimento. Atualmente somos também uma escola de educação infantil e fundamental, mas vamos primeiro a um pouco de nossa história.

Nascemos em fins de 1997 dentro do ateliê da artista plástica Elisa Bracher, em meio à esculturas, madeiras e fazeres. Era incômodo dela um Brasil cultural e socialmente cindido. Em uma tarde por semana, abriu seu ateliê, e juntamente

\footnotetext{
69 Trabalho apresentado na mesa "Criança: qual o mundo para ela?” no II Simpósio Bienal SBPSP "Fronteiras da Psicanálise: a clínica em movimento" no dia 22 de agosto de 2020.

${ }^{70}$ Mestre em Psicologia Clínica pela PUC-SP, Doutora em Psicologia Escolar e Desenvolvimento Humano pelo IP-USP, diretora do ateliê-escola ACAIA.
} 
com um marceneiro e sua serra circular, ofereceu espaço e tempo para escuta de algumas crianças. Tempo para saber delas, como moravam, do que gostavam, o que podiam ou não comunicar. Na qualidade de mãe de uma amiguinha de seu filho eu também frequentava o ateliê. Fazíamos pequenos objetos de madeira, conversávamos, e nos reuníamos nesta tarde que se encerrava com um lanche.

Fomos aumentando o número de vezes por semana e em 3 anos éramos mais de 50 crianças, divididas em manhãs e tardes para acompanhar o contra turno escolar.

Uma sede foi construída em 2001 e meticulosamente acompanhada pelos frequentadores. Abrimos o período noturno para receber as famílias, entender um pouco mais as histórias e entrelinhas do que vivíamos com as crianças.

Em 2005 fomos autorizados pela comunidade a frequentar livremente as favelas. Passamos a atuar dentro da favela e no final de um ano de atividades, no meio da viela, compramos um barraco. Barraco-escola, que como as atividades na sede, respeitaram o tempo para se estabelecer e ganhar credibilidade e confiança. Temos um barraco-escola em cada favela com atividades diárias. Recebemos crianças e famílias de todas as idades, sem muitas regras e levamos e trazemos notícias. Uma criança que não chegou a tempo para escola recebe o chamado dos educadores que estão a caminho das atividades do barraco. Dos educadores também, vêm notícias de uma batida policial, da situação de uma família mais vulnerável.

Os princípios que nos regem é o que imagino que deva valer para qualquer criança: respeito, atenção, lugar para fantasia, experimentação, pesquisa, comer, se frustrar, embater, ficar só, ficar só acompanhado.

Todo funcionário que trabalha no Acaia é um educador, do porteiro à direção, professores, cozinha e administração - estão sempre disponíveis para atender a um cuidado à despeito da função contratada.

Procuramos permanentemente conhecer o contexto em que vivem as crianças e famílias que atendemos. Vivemos muitas enchentes e incêndios, rotinas de desamparo, de violência doméstica e violência policial. Aprendemos a subir em escadas que acessam outros barracos e outros mais adiante, a por reparo em quantos cadastros para moradias já foram feitos sem encaminhamentos posteriores. 
Entendemos que as famílias precisavam também ser acolhidas, que o desamparo é em escala. Nos incêndios perdem-se documentos, é preciso orientação na conexão com os serviços públicos, ajuda com a Vara da Infância e Conselho Tutelar. Assim, constituímos um plantão jurídico para a comunidade.

O atendimento psicológico, emocional às crianças e famílias foi sempre tônica, nasceu em conjunto ao lugar de estar. Se há oficina de marcenaria, culinária ou costura, há também a oficina dos sentimentos. Importa aprender a se cuidar, falar sobre o que se sente, compartilhar histórias e dores, brincar em conjunto, de boneca, de médica, de monstro, de gravidezes e violências.

Aqui se coloca outro dos princípios fundamentais do Acaia: escolha que gera autonomia. Em muitas ocasiões são as crianças e adolescentes que escolhem em que atividade se engajar dentre as ofertas dos ateliês livres. Dirigem-se para a música ou para marcenaria, artes ou acampamento do livro.

Uma criança desatenta nas atividades pode abrigar muitos significados: não ter dormido com o barulho do som alto das vielas e bailes funks, pode estar com fome, pode ser anêmica ou estar com verminoses, pode estar muito triste por presenciar cenas que não consegue metabolizar. Pode também precisar de brincadeiras com graus de agressividade que muitas vezes não sabemos como acolher.

Fomos desenvolvendo um programa de saúde que começou a saúde mental e se expandiu para uma grade de parcerias em saúde bucal, oftalmológica, dermatológica, controle de anemia e verminoses, otorrino e fono.

Em 2017 nos tornamos uma escola privada e gratuita e celebramos o início com um culto ecumênico. Outro ponto muito importante a se destacar é buscar não hierarquizar os saberes de sala de aula e ateliês de fazeres, $\mathrm{A}$ estrutura curricular partiu do que já fazíamos no ateliê e chamar ateliescola frisa que os fazeres não estão à reboque, tudo junto e misturado. $\mathrm{O}$ cotidiano dos alunos integram aulas de experimentos e matemática, laboratórios e práticas de linguagem, música, artes e marcenaria, biblioteca e leituras em diversos formatos.

O material pedagógico é construído para o ateliescola e são utilizadas ilustrações feitas pelas crianças o que dá mais sentido às atividades. Apresentarse oralmente, escolher o que ler, expor-se, preparar a atividade em conjunto. 
Gosto de falar dos saraus e de um dia em que um aluno de primeiro ano que iria com seu grupo se apresentar para a turma do infantil 2 olhou para mim e suspreso falou: você acredita que eles não sabem o que é um sarau? Sarau "É o bicho!, sarau dos mais velhos, sarau nas favelas...

Pensar no Processo - outro pilar posto em todas as atividades. Tudo é construção, linguagem. Aprender a escrever - e olha que a lista de nomes da qual se parte não é moleza: Kathelyn, Amelie, Kaiversson...começar uma atividade no ateliê de artes e aguardar a próxima aula para continuar seu trabalho, terminar a tarefa deixando o espaço para a outra turma que irá ocupá-lo. Detalhes do dia a dia que se impõe na tarefa do educador e que dá a todos noções de etapas e planejamento.

O trabalho no Acaia tem alta expectativa sem desconsiderar o público e as dificuldades pelas quais passam as crianças. São muitos e diários os momentos em que um educador precisa conter uma criança que não conseguiu seguir com uma atividade, que se descontrolou, bateu, precisou ser retirada do grupo. Situações que levam todos à exaustão. Tivemos inclusive momentos de formação em equipe para aprender como conter uma criança de forma a não machucá-la e não se deixar machucar.

Assim, precisamos para atender uma criança em seu mundo, cuidar de quem cuida - família, equipe, comunidade.

A direção do Acaia é presente, cotidiana, completamente em consonância e orgânica ao dia a dia do ateliescola. As instâncias hierárquicas regulam as crianças embora seja também muito claro que na cozinha quem dita o tom é a cozinheira e sua equipe, na sala de aula ou nos ateliês são os educadores. Todos estamos submetidos à leis, inclusive o próprio funcionalmente de uma escola.

Tópicos para possível discussão:

Atividades com sentido

Relação não assistencialista (salvo em enchentes e pandemia)

Como nos relacionamos nos últimos três meses

Atividades entregues a cada 20 dias, cestas, visitas, posto de saúde, campanha de computadores, radio fala fi, estrutura de atendimento psicológico, áudios e whattsapp.

Identificação das famílias mais vulneráveis.

Relação com instituições do entorno. 